\title{
제 935차 DAC 상주대표 정례회의
}

\section{I. 회의개요}

표제 회의가 2011년 7월 12일에 파리 OECD 본부에서 OECD사무국(개발협력국) 주관으로 Brian Atwood DAC의장, 당관 정진규 참사관을 비롯한 각 회원국 DAC대표가 참석한 가운데 개최 됨.

\section{II. 주요내용}

- 향후 논의는 개발효과성을 추구하기 위한 새로운 글로벌합의(New Global Compact)도출 및 개 발효과성과 원조효과성의 균형과 연계, 주인의식-개발결과-책임성(ownership-resultaccountability)의 연계, 투명성(IATI 기준 승인여부), 원조 제공의 예측가능성, 다자기구의 효 과성, 개발효과성 도입 방식 등에 초점을 두고 진행 될 것이라고 전망 함.

- DAC의장은 부산총회의 성패는 새로운 글로벌 개발규범에 대한 합의도출에 달려 있으며 중요한 글로벌 행위자들을 금번 부산 프로세스에 어떻게 연계하는지가 관건이라고 언급하며 DAC과 주 최국인 우리나라의 역할을 강조 함.

- 다수의 회원국은 개발효과성으로의 전환에는 동의하나 개발효과성 논의에서도 파리/아크라선언 (PD/AAA)의 주요내용은 계속 핵심의제로 남아있어야 한다고 강조하였으며 '원조의 촉매역할'을 구체화하는 방안을 제시해야 할 것을 요청 함.

- 일부 회원국은 $\mathrm{OECD}$ 개발협력국이 부산총회의 주요 의제가 될 개발효과성과 관련된 일부 지표 를 선정, 지속적으로 모니터링 해나가는 것이 중요하다는 의견을 개진. 구체적인 Post-Busan 청사진 논의 필요성 제기 함.

- 새로운 개발원조위원회(New DAC)의 방향에 대한 논의가 있었으나 현재 OECD 개발전략 추진방 안, 부산총회 핵심성과물에 대한 예상이 확실하게 제시되지 않은 상황에서 DAC의 조직개편을 구체화하기 어렵다는 의견이 다수 제기되어 하반기에 동 사안을 다시 논의하기로 함.

- 최근 활성화되고 있는 개발관련 수평적 사업(녹색성장, 기후변화 대응 등)과 타 위원회와의 공동 작업(무역을 위한 개발, 조세와 개발, 식량안보 등), 부산총회 핵심성과물을 PWB에 반영하는 것 이 중요한 바, 하반기 PWB논의에서는 이러한 측면을 중심으로 대안을 만들어 가기로 함. 